\title{
THE SITE OF A FILM SET AS MATERIAL HERITAGE
}

\author{
A CASE STUDY OF THE POHJOLA \\ VILLAGE FROM RAUTA-AIKA \\ (THE AGE OF IRON) TV-SERIES
}

\author{
Janne Ikäheimo \\ University of Oulu \\ Archaeology, Faculty of Humanities \\ P.O. Box 1000, FIN-90014 \\ Finland \\ janne.ikaheimo@oulu.fi \\ Tiina Äikäs \\ University of Oulu \\ Archaeology, Faculty of Humanities \\ P.O. Box 1000, FIN-90014 \\ Finland \\ tiina.aikas@oulu.fi
}

\begin{abstract}
Rauta-aika (The Age of Iron, 1982), a four episode TV-series produced by YLE - the Finnish Broadcasting Company, transported the audience into a world of fantasy by successfully mixing the Finnish national epic Kalevala with elements of the local Iron Age. This paper focuses on the dismantled film set of the Pohjola village at the Seinävuori Hill in Hämeenkyrö, documented using archaeological methods in 2012, from the perspective of material heritage. While the remains visible today at the Seinävuori Hill are scarce, they continue to give a context for various meanings and experiences assigned to this place in the recent and more distant past and hence impact the heritagisation of the place.
\end{abstract}

Keywords: heritagisation, authenticity, filming site, contemporary archaeology

\section{Introduction}

A wanderer exploring the forest area by the Seinävuori Hill near the city of Tampere in southern Finland (Figure 1) may come across a series of deep cliffs and gorges exposed by the last glacial age. A narrow forest path leads to one of these cliffs, but at the end of the path nothing refers to a place of special significance. No signs of human activity are visible, but as one carefully descends to the foot of the hill, something peculiar can be spotted: the decayed remains of a small wooden shed and a section of the cliff face sooted by a substantial, large bonfire. These are the only apparent remains of the filming site of Rauta-aika (The Age of Iron). 


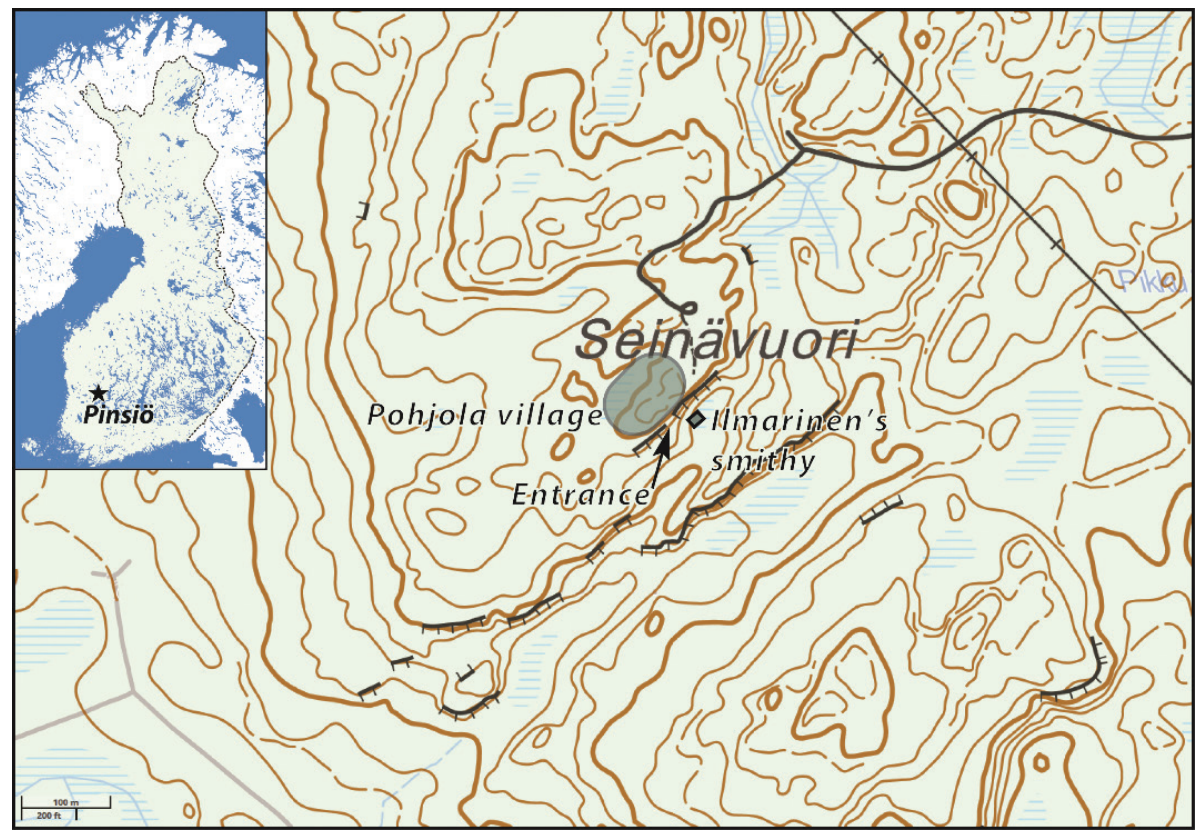

Figure 1. Location of the Seinävuori Hill and the archaeological remains (map: Ikäheimo, basemap @ Maanmittauslaitos 2015).

This four episode mini-TV-series produced by YLE - the Finnish Broadcasting Company and premiered in 1982 after four years of shooting, was at the time one of the biggest productions in the history of Finnish television drama. The budget of 5.3 million Finnish marks (approximately 2.7 million Euros) meant that it was also the most expensive TV production in Finland at that time. The airing of the TV-series in February-March 1982 produced somewhat mixed responses in the audience. The critics said that the series contained too much brutality, sported a cast with too many familiar faces and had wrecked national myths while being overly expensive to produce. ${ }^{1}$ Nevertheless, Rauta-aika was also a considerable success, especially among Finns with higher education ${ }^{2}$ and film critics, while its international broadcasting rights were sold to approximately twenty countries.

The screenplay of Rauta-aika written by author Paavo Haavikko was also published as an eponymous long poem. ${ }^{3}$ The storyline is loosely based on the Finnish national epic Kalevala which describes mythic Finnish heroes, their fights, their heroic but often failing feats, and their love lives full of lust and seduction. Spells and magic are integral to the stories. Nevertheless, Haavikko stripped Kalevala of its national romantic heroism and transformed the heroes who were rather pitiful, melancholic and unlucky to begin with into dirty, reticent and almost brutal characters. The material culture seen on the TV screen, on the other hand, combined elements from Kalevala's epic tales with Finnish ethnography and Iron Age archaeology. Still, both the author Haavikko and the director Kalle Holmberg emphasized the artistic presentation instead of the historical narratives. In particular, Holmberg stated that Rauta-aika is not attempting to portray the Iron Age, but is rather timeless in spite of incorporating historical and mythological elements. ${ }^{4}$

\footnotetext{
1 Pekka Laaksonen 'Rauta-ajan kevät', Suomalainen vuosikirja 1983, 1982, 104-112; Kimmo Laine and Hannu Salmi, 'From Sampo to The Age of Iron: Cinematic interpretations of the Kalevala', Journal of Finnish Studies, 13, 2, 2009, 78-80.

2 Pekka Vuoristo, 'Koulutettujen elokuva', Suomen Kuvalehti, 21/1982, 1982, 19-21.

3 Paavo Haavikko, Rauta-aika, Otava, 1982.

4 http://yle.fi/vintti/yle.fi/rautaaika/holmberg.html
} 


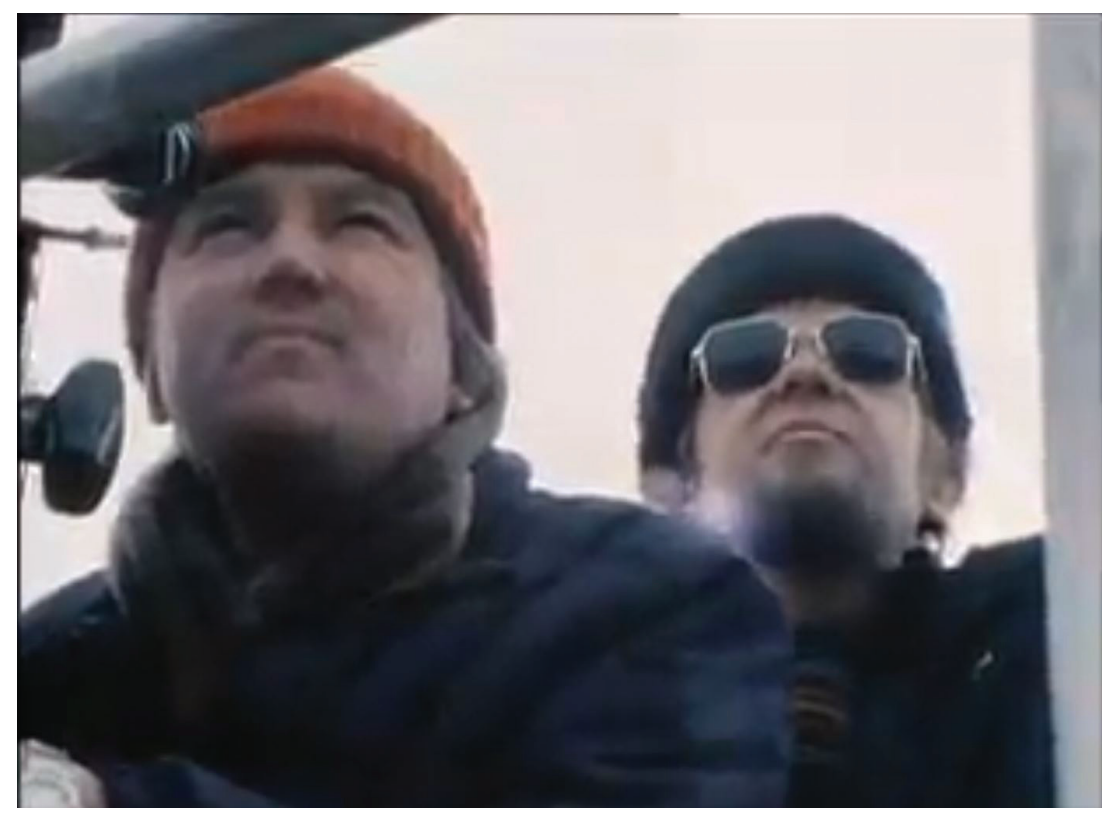

Video 1. Director Kalle Holmberg describes the making of Rauta-aika. The film set of "Pohjola" is shown the beginning of the film. (Rauta-ajan raportti, YLE 1982).

An important storyline in Rauta-aika focuses on a village called Pohjola commanded by Pohjan Akka (Kristiina Halkola), the evil witch of the North. The village is visited by two men from the southern village of Kalevala, Väinö (Kalevi Kahra) the shamanistic hero and IImari (Vesa-Matti Loiri) the blacksmith, who compete against each other to wed Pohjan Akka's daughter (Lena Meriläinen). To improve his chances of succeeding in this quest, Ilmari agrees to forge Sampo - depicted in Kalevala as a magical artefact of uncertain type bringing wealth and good fortune to its holder, and in Rauta-aika as a primitive coin mill - first promised to Pohjan Akka by Väinö without Ilmari's consent. The forging of Sampo and other scenes that take place in Pohjola were filmed at the Seinävuori Hill, where a film set comprising a palisade surrounding a mock Iron Age hill fortress with log houses, sheds and auxiliary buildings had been constructed.

\section{Aims and Scope}

This paper examines the material heritage of the film set built at the Seinävuori Hill from the perspective of contemporary archaeology - the study of modern remains with archaeological methods. This is a concept that has seldom been applied to television studies ${ }^{5}$, but it is highly relevant in the context of material heritage, as the film set location can be comprehended as an archaeological site. It is a place, where a specialized type of human action once took place and is therefore not so different, for example, from a Palaeolithic kill site.

We approach the material remains at Seinävuori Hill from the perspectives of heritagisation and authenticity. Heritagisation is a process where the memories, meanings, and ways of use connected to a place shape people's understanding of the place as heritage. Heritagisation is a product of the historicised present not necessarily 
originating in the past. ${ }^{6}$ Thus, the authenticity of a site is not necessarily important for heritagisation, whereas a personal connection and interaction with the site often become central aspects. ${ }^{7}$ In our case of experiencing a film site, embodied experiences of the place and aspect of existential authenticity, such as emotions, sensations and relationships, play a central role in the heritagisation and feeling of authenticity. ${ }^{8}$

The authenticity of a film location is an interplay between real and imaginary. Christina Lee has stated that shooting locations provide a site where fictional places become actualized and tangible. ${ }^{9}$ At a film location, a tourist engages with the filmic reality and constantly moves between the real and the fictional, imaginary place.$^{10}$ Here, the visitor's imagination, sensory experiences, and immersion play a central role. Even theme parks with no connection to the film site can have their own authenticity based on their multisensory aspects. ${ }^{11}$ At a film location, history and imagined history can also intertwine. Some of the tourists attending Lord of the Ring tours in New Zealand actually felt like they had been visiting archaeological sites. ${ }^{12}$

In Seinävuori, the natural location also affects visitor's experience. Stefan Roesch has separated natural features with special pre-attraction meaning (landmarks) and natural features without a special pre-meaning. ${ }^{13}$ Connection to a film can enhance meanings already existing at natural sites or create an altogether new cultural meaning for a natural attraction.

In the case of the Seinävuori Hill film set, we were interested to find answers to three questions. Firstly, what kind of material heritage had been preserved at the filming location that could be detected with archaeological methods? Secondly, how the material heritage or the lack of it affected the heritagisation of the site? And thirdly, we were interested in understanding the process that led to the current state of things visible at the site. As the latter question could not be answered through preserved material heritage, the accomplishment of these goals required two different conceptual approaches.

To find out what had been preserved of the film set in situ, we organised an expedition to the Seinävuori Hill in May 2012. The expedition formed part of a course called "Archaeology in popular culture" arranged by the University of Oulu. The aim of the fieldwork was to locate and to map material remains connected with the filming of the Rauta-aika TV-series. To accomplish this, we combined traditional techniques of archaeological surveying with less often-used methods. First, we searched for any traces of the film set, which for us represented archaeological remains, and related land formations by using the prints of screen captures from the Rauta-aika DVD. These prints were compared with the formations in the landscape to determine where different pieces of the film set had once stood. Thereafter we documented all the located features and remains by making notes and with digital photography. Stefan Roesch has described this type of action where a tourist - or in this case the researchers - takes photos from the same angle as in the film as 'capturing the filmic gaze'. ${ }^{14}$ As the mapping of

6 Ana Milošević, 'Historicizing the Present: Brussels Attacks and Heritagization of Spontaneous Memorials', International Journal of Heritage Studies, 24, 1, 2017, 53-65.

7 On authenticity cf. Cornelius Holtorf, 'On Pastness: A Reconsideration Of Materiality in Archaeological Object Authenticity', Anthropological Quarterly, 86, 2, 2013, 427-444.

8 Jillian M. Rickly-Boyd, 'Existential Authenticity: Place Matters', Tourism Geographies: An International Journal of Tourism Space, Place and Environment, 15, 4, 2013, 680-686; Anne Buchmann, Kevin Moore and David Fisher, 'Experiencing Film Tourism: Authenticity \& Fellowship', Annals of Tourism Research, 37, 1, 2010, 229-248.

9 Christina Lee, 'Have Magic, Will Travel': Tourism and Harry Potter's United (Magical) Kingdom', Tourist Studies, 12, 1, 2012 , 52-69.

10 Stefan Roesch, The Experiences of Film Location Tourists, Channel View Publications, 2009, p. 66.

11 Abby Waysdorf and Stijn Reijnders, 'Immersion, Authenticity and the Theme Park as Social Space: Experiencing the Wizarding World of Harry Potter', International Journal of Cultural Studies, 21, 2, 2018, 173-188.

12 Buchmann et al., 'Experiencing Film Tourism: Authenticity \& Fellowship,' 2010.

13 Roesch, The Experiences of Film Location Tourist, 2009, p. 65.

14 Ibid., p. 135 
these archaeological remains with real-time kinematic GPS turned out to be impossible due to dense forest and steep cliffs at the site, their positions were approximated and marked on a base map (Fig. 1).

To understand the processes that led to the current state of things observable at the site, we sought information from various sources. Firstly, we approached the people and institutions that might have preserved at least some documentation both regarding the filming of the TV-series and its aftermath. However, the contacts established with YLE - the Finnish Broadcasting Company and the municipality of Hämeenkyrö, where the Seinävuori Hill is located, produced only meagre results. The former institution could provide us only with a few additional photographic stills taken during the filming, while the latter could not produce a single document related to shooting at Seinävuori Hill.

Fortunately, during our expedition we met by chance Mr. Rauno Antinmaa, a local farmer and the former president of the local hunting fraternity. Mr. Antinmaa had not only participated actively in the filming process in the early 1980s, but as a member of the hunting fraternity he had also been highly involved with the subsequent endeavour to turn the film set into a temporary amusement park. Thus, we conducted a 58-minute semi-structured interview with Mr. Antinmaa. It highlighted the social importance of the filming and the significance of material remains remaining at the site after the film crew had left Seinävuori.

The various strains of information provided by Mr. Antinmaa were not taken at face value, but they were double-checked for their correctness using a variety of contemporary texts - newspaper and magazine articles - as well as later biographies and scholarly articles related to the Rauta-aika TV-series. Not only did these sources corroborate to a great extent the words of Mr. Antimaa, but they also offered a significant amount of hints on the process by which the film set disappeared from the Seinävuori Hill in addition to related opinions and visions expressed about its future. From this point of view, the biography of scenographer Ensio Suominen ${ }^{15}$, who was responsible for envisioning the various sets used in the filming of Rauta-aika, was of the utmost importance.

\section{The Scarce Archaeological Remains of Pohjola}

The remains of the fictional village of Pohjola discovered both on the top of and adjacent to the Seinävuori Hill are best introduced through the description of two important scenes in the Rauta-aika TV-series.

The first scene shows the overall setting of the village as Väinö the wizard arrives in Pohjola. The village is built to resemble an Iron Age hill fortress surrounded by a wooden palisade with a complicated entrance formed by narrow paths on otherwise steep, nearly vertical cliffs. Life in the village is portrayed as a violent dystopia under Pohjan Akka's autocratic rule with crumbling sheds, malnourished subordinates wading in filth, and ferocious dogs nourishing themselves on the carcasses of the slain humans and animals. Väinö enters this realm through the main gate and the camera follows his movement to the main square of the village where he encounters Pohjan Akka for the first time. 


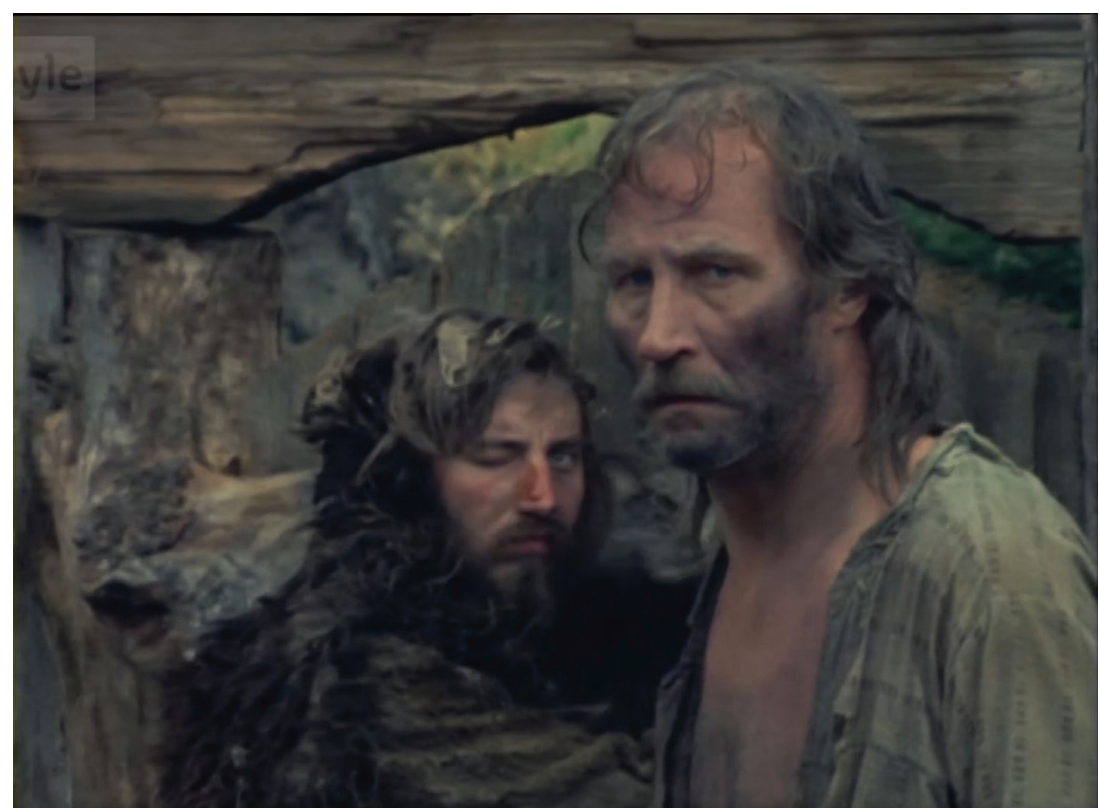

Video 2. The arrival of Väinö to somewhat brutal "Pohjola”. (Rauta-aika, YLE 1982).

The second scene set in Pohjola illustrates the difficult quest of Ilmari to forge the Sampo. The action takes place at the foot of the hill on which the village of Pohjola has been constructed. Ilmari the blacksmith and his subordinates spend a long time at the site forging the Sampo; autumn turns into winter and winter turns into spring before the goal is finally achieved. In the meantime, IImari has lit a large bonfire at the foot of the cliff, possibly to extract metal for the Sampo, constructed a shed for his smithy and painted hieroglyph-like inscriptions to the adjacent cliff face. After IImari has succeeded in forging the Sampo, the action moves elsewhere and the village of Pohjola is shown only once more in the series.

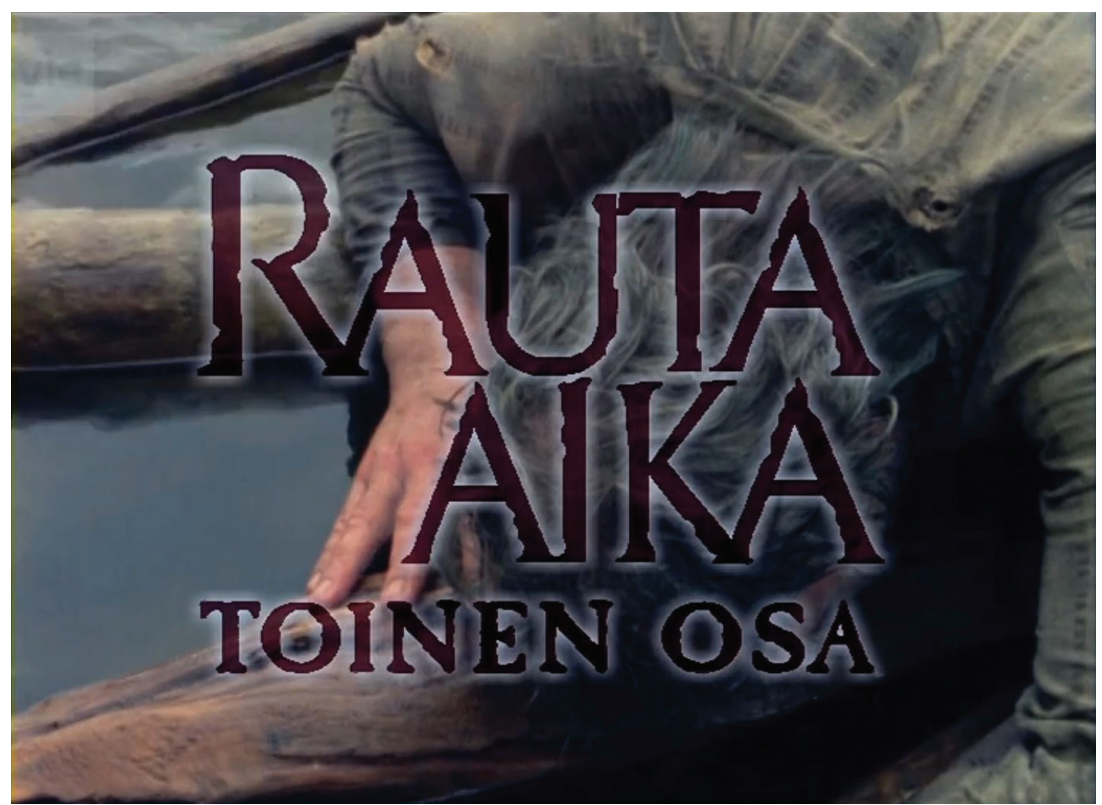

Video 3. Ilmari forging the Sampo. (Rauta-aika, YLE 1982).

Finding the exact locations where the filming of the scenes described above had taken place was not overly difficult for a group of archaeology students led by two trained archaeologists. While the wooden palisade had been recycled 
for building materials and the inscriptions painted by IImari had weathered away, the edges and other features of the cliff face had remained almost unaltered and were therefore still recognizable when compared with the still pictures (Figures 2 and 3 ) despite considerable changes in vegetation over the past three and a half decades. The fieldwork resulted in the identification of the following features.

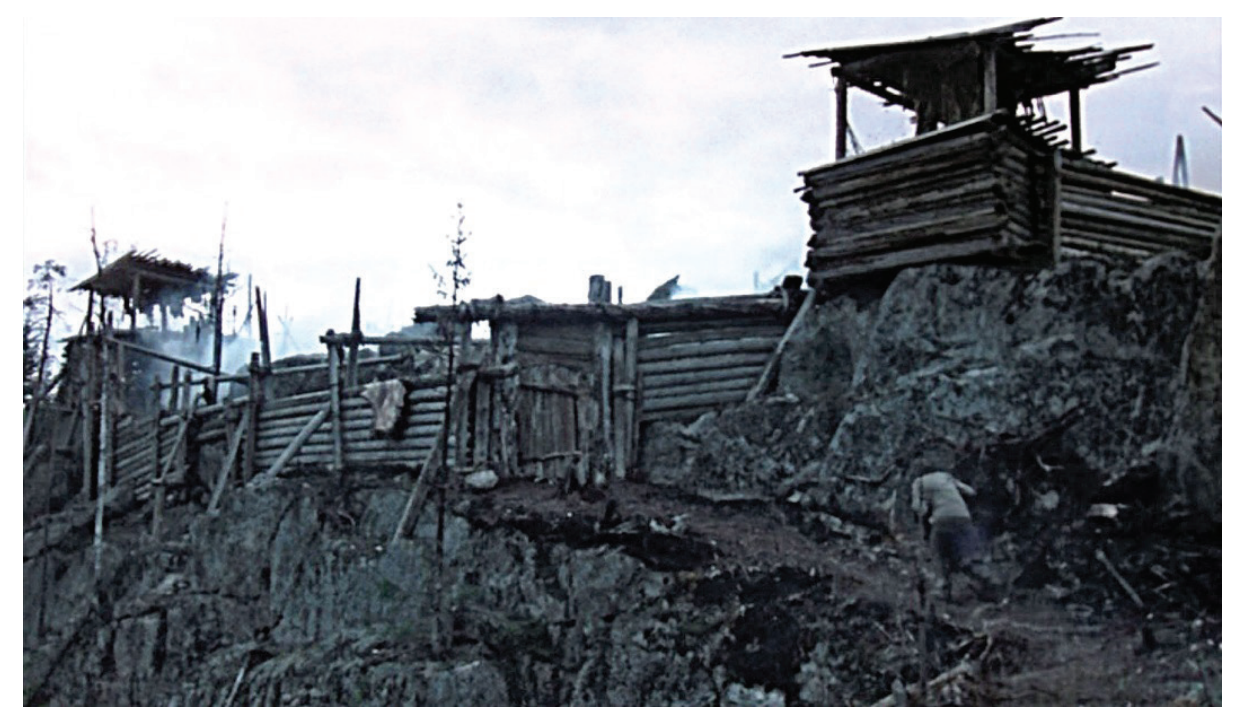

Figure 2. A screen capture from Rauta-aika showing the arrival of Väinö in the Pohjola village (YLE - the Finnish Broadcasting Company).

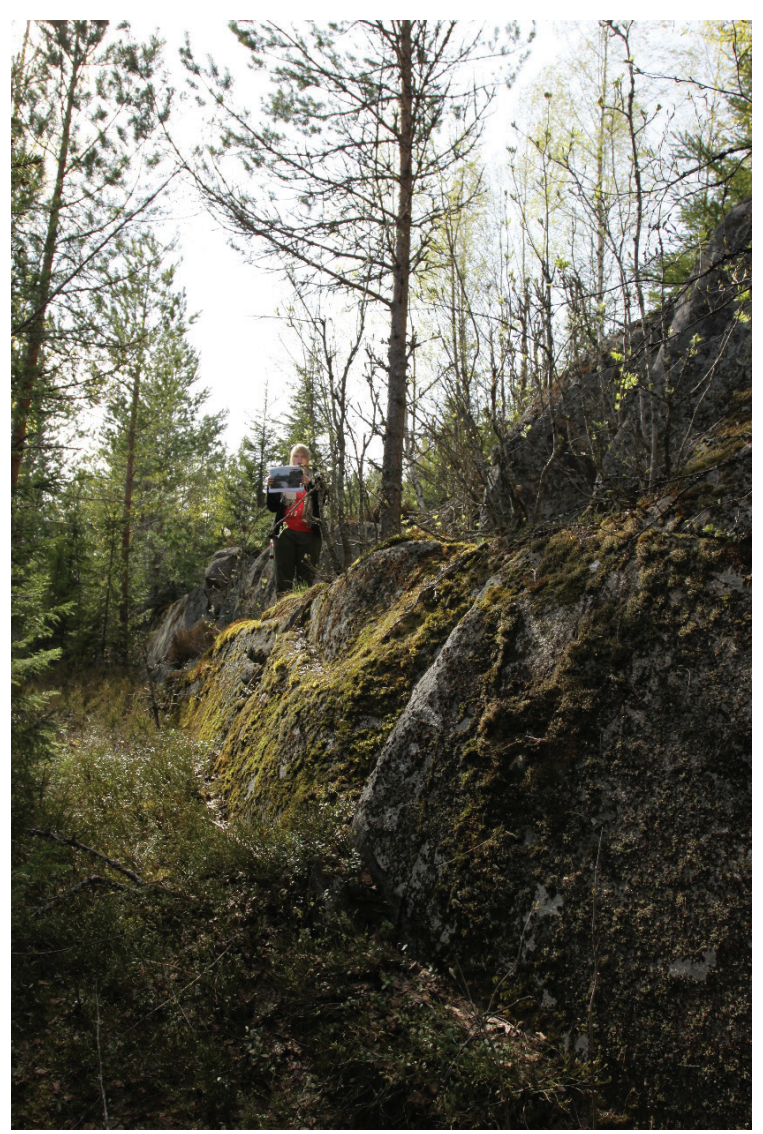

Figure 3. The section of the Seinävuori Hill where the entrance ramp to the Pohjola used to be (Photo: Äikäs). 
At the foot of the hill, the authors identified two prominent features. The first was the remains of llmari's smithy, of which the lowermost courses of log walls were still standing while the upper wall and the roof seemed to have collapsed a while ago (Figures 4 and 5). The second was the cliff surface against which the great bonfire had been kept by IImari's assistants; it was surprisingly easy to discern due to the heavily sooted cliff face. In addition, the part of the cliff where IImari drew his hieroglyphs was identified after a search with still pictures although the actual hieroglyphs had disappeared without a trace.

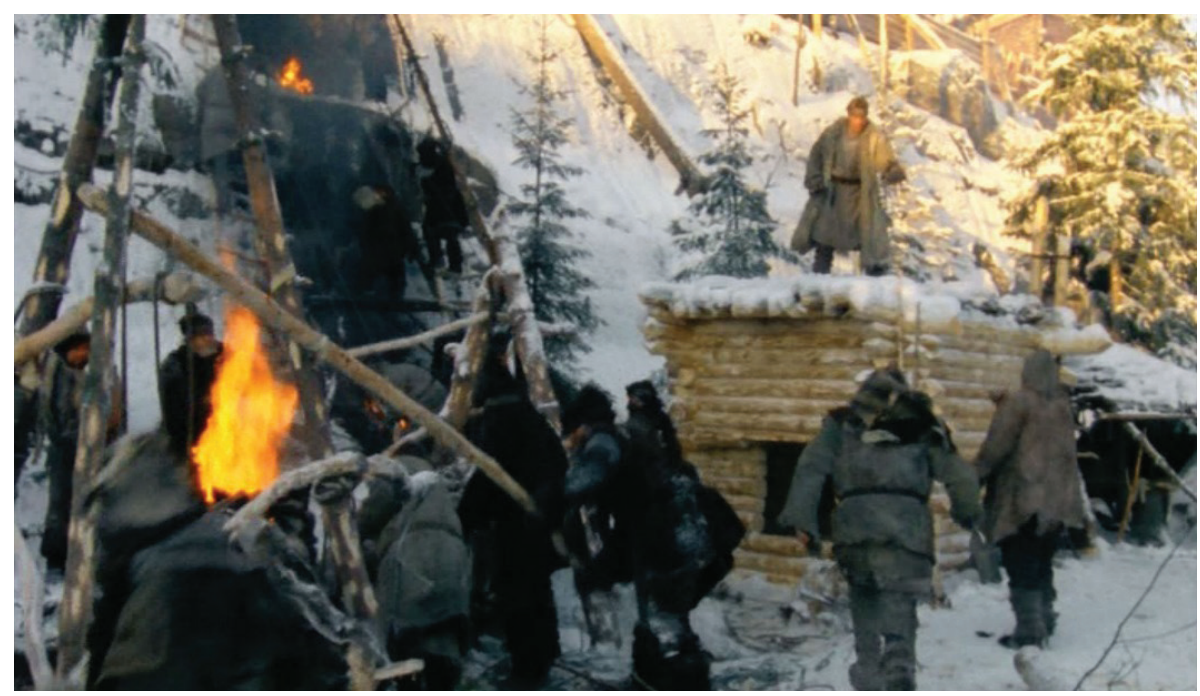

Figure 4. A screen capture from Rauta-aika with the smithy of IImari and the great bonfire used for forging the Sampo (YLE - the Finnish Broadcasting Company).

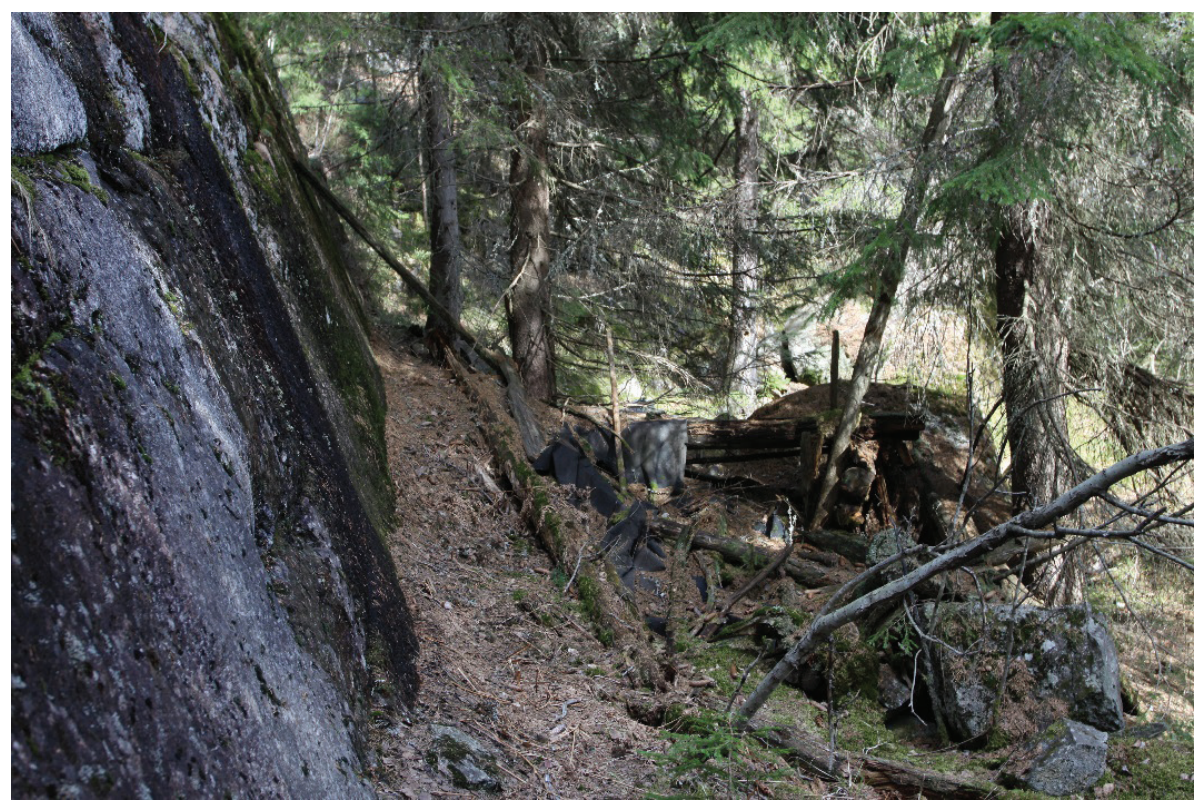

Figure 5. The remains of the smithy and the blackened surface of the cliff is all that remains from the set in figure 4 (Photo: Äikäs).

Archaeological material that could be connected to the village of Pohjola on the top of the Seinävuori hill was even scarcer. The main entrance was identified mainly due to the steepness of the cliff; the hilltop could not be accessed from any other direction except where the gate was located. On the hilltop, the foundations of some sheds and other 
edifices were recognizable as hardly visible shallow stone settings. Loose finds on the hilltop were also rare as they were limited to a single door hinge (Figure 6) belonging to one of the sheds. Empty alcohol bottles found on the hilltop were most likely related to a later use of the site. The very limited number of finds as well as the lack of material evidence from the structures pointed to the extensive spoliation of the site sometime between the filming in the 1980s and the visit in 2012.

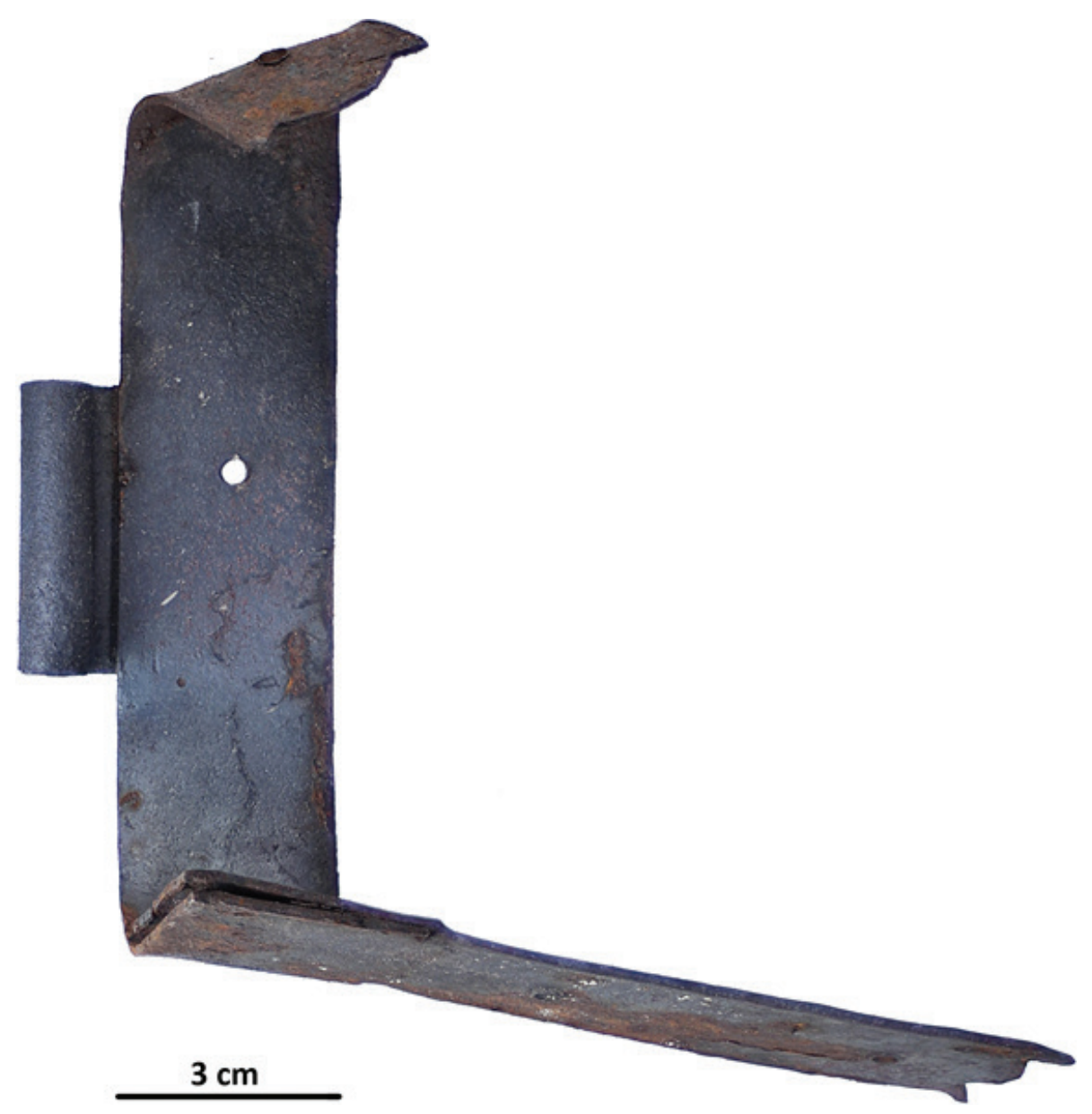

Figure 6. A door hinge found from the Seinävuori Hill (Photo: P. Pelttari).

\section{From a Theme Park In-PIanning into Oblivion?}

In a somewhat different turn of events, the references to Rauta-aika could have had a stronger and longer-lasting presence at the Seinävuori Hill. When the scenes taking place in Pohjola had been shot, the carefully constructed film set - scenographer Ensio Suominen constructed his vision by extensively studying local ethnographic and archaeological data - had fulfilled its primary function. The heritagisation of the set became apparent after the first airing of the TV series in spring 1982, when the site began to attract curious visitors from both near and far. The same thing happened with the film set of the Kalevala village constructed in Ilomantsi in south-eastern Finland, which had been defined as a "cultural monument" ${ }^{\text {"6 }}$ even before a single episode had been shown on TV. Around the same time, 
a temporary exhibition based on props tailor-made for Rauta-aika opened at the Tampere Art Museum. Thus, it is safe to say that the material heritage of Rauta-aika was momentarily in vogue.

This interest and appreciation shown by the public led to a vanguard idea in the context of the early 1980s about turning the site of the Pohjola village into a tourist attraction and into a sort of theme park. The actual plan of the local hunting fraternity was to keep the site open for visitors for a couple of days a week and have someone present at the site to tell people about it. The project would have supposedly lasted for a year or two, but no plans to establish a permanent theme park were ever made. These visions never took off, as they were deemed too expensive: the site would have needed constant maintenance and active participation in its upkeep, while there was no real guarantee that the flow of visitors to the site would continue in the future ${ }^{17}$.

Thus, the set was slowly dismantled. First, the animal carcasses and hides were transported away and this was done for a good reason - for long a hideous smell of rotting flesh had surrounded the Seinävuori Hill ${ }^{18}$. The local hunting fraternity gained ownership of timber structures that had been ordered and paid for by YLE. These were given in exchange for the extensive site clean-up, a task YLE would have otherwise been responsible for. Next, the structures were taken down and most of the resulting timber was sold at auction in April 1983'19. Only a single log hut, the one that had served as "The House of the Master of Pohjola" in the TV-series (Figure 7), was left intact and later recycled by the hunting fraternity into a lodge located a kilometre away from the Seinävuori Hill. For its members, the memories related to the filming of Rauta-aika and its aftermath have a tangible place even today, although this piece of material heritage is no longer standing on the top of the Seinävuori Hill.

Surprisingly, after the village of Pohjola set had been dismantled at the Seinävuori Hill, the site continued to attract visitors according to Mr. Antinmaa. These were mainly locals who took their guests to see the site in a similar way people used to take their guests to museums in towns, but also visitors from further away still found their way there. Nowadays the number of people visiting the site has diminished drastically, but a couple of visitors still show up there every year. As Mr. Antinmaa puts it: "The fever is over."

Currently there are also several barriers ${ }^{20}$ hindering access to the Rauta-aika film site at the Seinävuori Hill hence affecting negatively its heritagisation. A locked boom barrier blocks the only drivable road to the site. Visitors reaching the site by foot might not find the exact location due to scarce remains and changed vegetation. A local entrepreneur and culture enthusiast Ms. Katariina Pylsy, who had visited the site herself once before organising a nature and landscape day trip there, states that "now no-one can find the place". ${ }^{21}$ She would like to see the site developed with planned thinning and by installing signs and steps - as the steep cliffs form a serious safety issue - in addition to the preparation of a tourist guide map.

From the chronological point of view, our expedition to the site exposed a new facet in the site biography, as the remnants of its material heritage became the subject of archaeological enquiry. Nonetheless, this does not mean that the previous meanings associated with the site would have simultaneously ceased to exist, as will be pointed out in the following discussion.

17 Rauno Antinmaa, an interview in Pinsiö, Finland 15 May 2012, conducted by Ikäheimo and Äikäs; cf. Kimmo Laine and Hannu Salmi, 2009 , p. 82.

18 Antinmaa, interview, 2012.

19 Kalemaa, Ensio Suominen, 2008, p. 189.

20 Roesch, The Experiences of Film Location Tourist, 2009, p. 78.

21 Katariina Pylsy, a phone interview, 11 May 2019, conducted by Äikäs. 


\section{Discussion}

The evidence on the filming of Rauta-aika is scarce on the Seinävuori Hill. Virtually all the structures seen in the TV-series have been dismantled and their exact locations are hard to depict without screenshots of the film. Even features in the landscape are difficult to recognize due to changes in vegetation. Thus, the site represents a rather tough challenge for an ordinary person on a quest to find the material heritage or the landscape of Rauta-aika. For example, when Mrs. Pylsy visited the site, she saw nothing that pertained to the filming of Rauta-aika. ${ }^{22}$

Moreover, some elements foreign to the real site were added in the cutting stage. The most noticeable of them is the absence of a large body of water that the men of Kalevala had to cross to reach the foothill of the cliff on the top of which the Pohjola village is located. It was obviously filmed in another location. Hence, the experience of people visiting the filming site must have differed from the Pohjola village shown in Rauta-aika from the beginning.

Location discrepancies or distortions occur where imaginary places and real locations differ in their mutual recognition value and it has been shown that visitors can find these kinds of distortions from filmic reality either disturbing or interesting. ${ }^{23}$ Still, tourists engaging with a film site can benefit from mental images where the imaginary mentally overlaps with the real so that visitors can mentally see the absent objects, ${ }^{24}$ hence it is not essential that the remains are actually in place. The reported visits to the site, even after three decades from the first airing of the TV-series, indicate that people do not necessarily seek to relive the Pohjola village as it was seen on TV.

Although the TV-series and the related filming process have given new meanings to the Seinävuori area, it is up to each visitor's subjective choice ${ }^{25}$ whether to use them to augment their own sensory experience. The Seinävuori Hill also attracts visitors with its natural beauty similar to New Zealand, where the Lord of the Rings tourists wish to see both the "real" New Zealand and the more fantastical Middle-Earth ${ }^{26}$. Sue Beaton has stated that natural attractions can gain a higher status through an association with a film. ${ }^{27}$ The Seinävuori area can also be seen to have some pre-attraction natural values, although it is not considered as a landmark. One interviewee stated that he was fascinated by an old forest area so close to a city and the cliffs were also beautiful. He had also noted a historical passageway that is located close by. ${ }^{28}$

Still, fiction has the potential to offer a powerful interpretation of the landscape that in turn affects the perception of real places. Kronborg Castle in Denmark has become known as the home of Hamlet and the hill of Tara in Ireland has gained additional meanings from the novel Gone with the Wind ${ }^{29}$. Thus, the link between the scenes described and depicted in fiction and the "real" landscape tends to blur. ${ }^{30}$ The emotions experienced when watching a movie or reading a book are transferred to "fictional" places when people visit them and they become imbued with powerful meanings even though visitors are well aware of their fictional nature. ${ }^{31}$ The importance of such places is

\section{Ibid.}

23 Roesch, The Experiences of Film Location Tourist, 2009, p. 151-152.

24 Ibid., p. 141.

25 David Herbert, 'Literary Places, Tourism and the Heritage Experience', Annals of Tourism Research, $28,2,2001$, p. 317.

26 Anne Buchmann, 'Planning and Development in Film Tourism: Insights into the Experience of Lord of the Rings Film Guides', Tourism and Hospitality Planning \& Development, 7, 1, 2010, 77-84.

27 Sue Beeton, Film-induced Tourism, Channel View Publications, 2005.

28 Anonymous e-mail interview, 3 May 2019, conducted by Äikäs.

29 cf. Mike Robinson, 'Reading Between the Lines: Literature and the Creation of Touristic Spaces', Current Writing: Text and Reception in Southern Africa, 14, 1, 2002, 1-28.

30 Film geography and film theory use the concepts of "real" and "reel" to describe what the camera has filmed ("real") and what can be seen as an image on the screen ("reel”). See, e.g., Lisa M. Benton, 'Will the Real/Reel Los Angeles Please Stand Up?', Urban Geography, 16, 2, 1995,

144-164; Chris Lukinbeal 'Cinematic Landscapes', Journal of Cultural Geography, 23, 1, 2005, 3-22.

31 Herbert, 'Literary Places, Tourism and the Heritage Experience', 2001, 316; Deborah Dixon, 'Film, Geography and', in Barney Warf, ed, Encyclopedia of Human Geography, Sage, 2006, p 166; Dydia DeLyser, 'Literature, Geography and', in Barney Warf , ed. Encyclopedia of Human Geography, Sage, 2006, pp. 278-280. 
demonstrated, for example, by the popularity of literary guided tours following e.g. the footsteps of Leopold Bloom in Dublin; the Jane Austen tour in Bath, which is the setting for her novels Northanger Abbey, and Persuasion; or the Millennium tour in Stockholm inspired by Stieg Larsson's novel The Girl with the Dragon Tattoo.

It is evident that during our visit to the site our experiences differed considerably from ordinary visitors, because as archaeologists we had assigned a somewhat special meaning to it. For us, the Seinävuori Hill filming site was a target that we had to locate, reach, research and interpret in the light of a short-lived event that took place there in the early 1980s. For the locals the site with its surroundings is an ever-present and integral component of their lived environment. Perhaps our visit to the Seinävuori Hill in May 2012 could be best described as an act of academic confiscation. We carried out an archaeological ritual by arranging "an expedition" to the site and trying to act like "good" archaeologists equipped with high-end gear for documentation - like the real-time kinematic GPS that did not function - and wearing our trusted field gear.

Still, the research process included all the necessary elements: the recognition of archaeological remains and objects, documentation by photography and the initial interpretation of what we had observed. Due to our academic background, we were bound to treat the place as an archaeological site. Our focus was mainly on the material heritage that had resulted from an event of relatively short-duration in the recent past. The fixation on material remains and objects was similarly obvious during the archaeological documentation of a filming site of Castaway 2000 TVseries in Taransay, Scotland. ${ }^{32}$ For us the landscape was significant only because it potentially concealed material evidence pertaining to the activities that took place during and after the filming of Rauta-aika TV-series.

Of course, defining the location of a film set that is barely forty years old as a relic that possess heritage values worth protecting, might at first seem to be a somewhat extreme proposition. On the other hand, the idea is not that different from what has been put forward in the current debate concerning popular music heritage. Today, authorized heritage discourse has matured to the point that it can accommodate the one-time home/rehearsal space of the notorious Sex Pistols on 10 Denmark Street in London with its walls covered with caricature graffiti drawn by John Lydon (a.k.a. Johnny Rotten). ${ }^{33}$ Still, the emphasis on treating film sites as material heritage should be on their documentation rather than preservation. In the opposite case, the most likely outcome is a haphazard collection of locations that have been frozen in time through protective legislation. While professionals of material heritage, such as archaeologists could carry out the documentation, there is no apparent reason why this responsibility should be exclusively theirs. As with preserving popular music's material heritage ${ }^{34}$, a community based approach applying do-it-yourself strategies and disseminating the results via the Internet might produce the most fruitful results.

Finally, for the locals like Mr. Rauno Antinmaa the site and its surroundings have a different kind of meaning. Instead of being concerned about material heritage or, in this particular case, the lack of it, their memories are focused on the action that once took place at the site and the moments shared with the locals and the cast. The shooting of Rautaaika employed local people in the building of the set from thirty recycled hay barns ${ }^{35}$, and the filming itself was an event of local pride. A site in the small agrarian municipality of Hämeenkyrö was selected by YLE for filming and the locals got to know and some even befriended nationally famous actors and film crew. While some of these friendships lasted for several decades and the production left a lasting mark among the local people, the time did not stop - the Seinävuori Hill continued to be a part of a dynamic landscape to which the site of the film set added just one, although very peculiar layer - the past moments are mainly cherished in memories.

32 Hayden Lorimer and Fraser MacDonald, 'Cultural Geographies in Practice: A Rescue Archaeology, Taransay, Scotland', Cultural Geographies, 9, 2002, 95-102.

33 See Paul Graves-Brown and John Schofield, 'The Filth and the Fury: 6 Denmark Street (London) and the Sex Pistols', Antiquity, 85, 2011, 1385-1401; Paul Graves-Brown and John Schofield ,'The most awkward building in England'? The 'Rotten' Heritage of 'Tin Pan Alley' Revisited', Antiquity, 90, 2016, 1629-1642.

34 E.g. Sarah Baker, Community Custodians of Popular Music's Past: A DIY Approach to Heritage, Routledge, 2017.

35 Kalemaa, Ensio Suominen, 2008, p. 169. 
J. Ikäheimo and T. Äikäs, The Site of a Film Set as Material Heritage

\section{Conclusions}

This case study on the filming site of Rauta-aika strongly suggests that a place which archaeologists might be keen to interpret as a fictional reinterpretation of the past is likely to contain altogether different meanings for other people. That the intention of the TV-series was not to try to depict a realistic past was pronounced already during filming; no excessive emphasis was put on the authenticity of the set or clothes because the intention was not to strive for historical credibility ${ }^{36}$. As the props and other material evidence related to filming have essentially disappeared today, the locals construct the meaning of this place differently: it is a place of local pride and personal as well as communal memories.

The need for permanent infrastructure, a theme park based on Rauta-aika for remembrance, was considered but it was deemed uneconomical. The only standing material evidence of the filming, the log hut, was preserved and relocated; and it gained new meanings and functions as a hunting lodge. Hence, the authenticity of the place lies in stories and memories about the former life of the structure. As Prentice ${ }^{37}$ has observed, authenticity can be created through different things. Here the relevant features are the location where something significant happened, associations with famous people and national, or in this particular case local, pride. The connection to the distant past is less relevant than to the events that took place some thirty years ago.

As the material evidence of the connection between real and reel becomes more subtle and more difficult to interpret, the place becomes more intimate. People like Mr. Rauno Antinmaa think that the knowledge regarding the Seinävuori Hill as a special place is still present and alive in the local community: "Kyllä paikalliset henkilöt muistaa ja näkee [...] Joka maastoja tuntee, tietää sen paikan", translated, "Locals do remember and see [...] Who is familiar with the terrain knows the place."

\section{Biographies}

Janne Ikäheimo works as a lecturer in archaeology at the University of Oulu. While his dissertation (2003) focused on ceramic cooking pots produced in Roman Africa, his current research topics include contemporary archaeology, the early medieval period in Northern Finland and the heritagization of popular music. He is also interested in the material culture and sociology of recent "craft beer revolution".

Tiina Äikäs is a researcher working in archaeology at the University of Oulu. Her dissertation (2011) focused on the landscape analyses and site biographies of Sámi offering sites including their use from Iron Age to present. Her research interests include contemporary archaeology, ritual archaeology, and the use of interviews in archaeological research. She is interested in studying the meanings given for cultural heritage in the contemporary world.

36 Pekka Laaksonen, 'Rauta-ajan kevät', 1982, p. 107.

37 Richard Prentice, 'Experiental Cultural Tourism: Museums \& the Marketing of the New Romanticism of Evoked Authenticity', Museum Management and Curatorship 19, 1, 2001, 17-21. 